\title{
Effect of Electrokinetic Pollutant Removal on the Status of Some Macro and Micro Elements in Saline Soil

\author{
Ahmed M. Abou-Shady ${ }^{1}$, Doaa T. Eissa ${ }^{1}$, Osama M. Abdelmottaleb ${ }^{1}$ and Rehab H. Hegab ${ }^{2}$
}

\begin{abstract}
Soil electrokinetic remediation is an appropriate technique to remove pollutants from soils particularly in low permeability soil. Recently, a new variation of soil electrokinetic remediation (SEKR) known as perforated cathode pipe SEKR system (PCPSS) was investigated for heavy metals removal and land reclamation. The PCPSS was enhanced for the removal of heavy metals via introducing the vertical anode/perforated cathode pipe SEKR system (VA/PCPSS). In the present work, the behaviors of associated macro and micro elements were investigated during the removal of heavy metals from soil via either the PCPSS or the VA/PCPSS. The results indicated that, calcium $\left(\mathrm{Ca}^{2+}\right)$ depleted from the top surface of soil specimen and accumulated close to the perforated cathode pipes when the PCPSS was applied. The depletion of $\mathrm{Ca}^{2+}$ was noticeably detected in the middle of specimen via installing the VA/PCPSS. The removed magnesium $\left(\mathrm{Mg}^{2+}\right)$ was lower than $\mathrm{Ca}^{2+}$, and it tended to desorb from the soil layer around anode and reabsorbed again in the subsequent layer during the application of the PCPSS. This accumulation disappeared when the VA/PCPSS was applied. The removal of potassium $\left(\mathrm{K}^{+}\right)$was lower in the top layer of soil when the VA/PCPSS was installed that may increase its applicability during soil reclamation. Boron accumulated around anode in the PCPSS system. On the other hand the application of the VA/PCPSS shunned this behavior. Molybdenum (Mo) tended to osculate during the application of the PCPSS, however the application of the VA/PCPSS resulted in high removal rate of $M o$ at the end of anodes and around cathode pipes.
\end{abstract}

Keywords: Electrokinetic remediation; PCPSS; VA/PCPSS; Macro elements; Micro elements

\section{INTRODUCTION}

Soil pollution with heavy metals has been widely increased due to industrial revolution particularly in last decades. Also, reusing of wastewater in agriculture purpose has negatively increased the concentrations of organic and inorganic pollutants containing agricultural soil. There are several approaches have been taken to remediate polluted soils including physical, chemical, and biological treatments. Soil electrokinetic remediation (SEKR) is one of physical remediation approach that fits low permeability of the soil polluted with heavy metals, organic pollutants, and radioactive materials (Abou-Shady, 2012, Abou-Shady, 2016a, Abou-Shady, 2017).

Recently, a modern technology have been introduced for land reclamation and heavy metals removal known as perforated cathode pipe SEKR system (PCPSS) to remediate heavy metals containing polluted soils with high efficiency. Also, the PCPSS was investigated as a possible technique that may be used to achieve land reclamation to avoid the consumption of large amounts of water and to ensure the sustainability (Abou-Shady, 2012; Abou-Shady and Peng, 2012; Abou-Shady, 2016b). The performance of the PCPSS has been recently improved via introducing five new designs to remove eight heavy metals from saline clay soil. The most convenient design proposed to improve the performance of the PCPSS was the vertical anode/perforated cathode pipe SEKR system (VA/PCPSS) in which several goals have been achieved such as preventing the formation of a $\mathrm{pH}$ jumping zone, prevention of the formation of an unsaturated zone, and consumption of a comparatively low amount of water (Abou-shady et al., 2018).

The aim of this study was to evaluate the behavior of some macro and micro elements including calcium $\left(\mathrm{Ca}^{2+}\right)$, magnesium $\left(\mathrm{Mg}^{2+}\right)$, sodium $\left(\mathrm{Na}^{+}\right)$, potassium $\left(\mathrm{K}^{+}\right)$, boron (B), and molybdenum (Mo) during soil electrokinetic remediation in saline soil using either a perforated cathode pipe SEKR system (PCPSS) or the vertical cathode/perforated cathode pipe SEKR system (VA/PCPSS). Based on literature survey there are no available articles focused on the effects of soil electrokinetic remediation on the behavior of such associated elements that may be affected with the passed current. This evaluation is very important to ensure the rehabilitation of polluted soils particularly those under agriculture uses.

\section{MATERIALS AND METHODS}

\section{Soil properties}

Saline clay soil was contaminated with different heavy metals and treated using the PCPSS and the VA/PCPSS according to Abou-shady et al., (2018). The chemical and physical properties of soil are listed in Table 1. Soil electrical conductivity was $9.18 \mathrm{dS} \mathrm{m}^{-1}$ for

${ }^{1}$ Laboratory of Water \& Soil Chemistry, Water Resources and

Desert Soils Division, Desert Research Center, El-Matariya 11753, Cairo, Egypt.

${ }^{2}$ Soil Fertility and Microbiology Department, Water Resources and

Desert Soils Division, Desert Research Center, El-Matariya 11753, Cairo, Egypt

Received February 14, 2018, Accepted March 14, 2018 
supernatant extracted from soil water ratio $1: 1$. Soil $\mathrm{pH}$ was close to neutral condition. The concentrations of $\mathrm{Na}^{+}$represented the highest values among cations followed by $\mathrm{Ca}^{2+}>\mathrm{mg}^{2+}>\mathrm{k}^{+}$(Table 1 ). On the other hand, $\mathrm{Cl}^{-}$represented the highest concentration among anions followed by sulfate. This indicated that, the saline soil was rich in $\mathrm{NaCl}$ content. The hydraulic conductivity was $1.83 \times 10^{-4} \mathrm{~cm} \mathrm{~s}^{-1}$.

Table 1 The main soil chemical and physical properties of the used soil (Abou-shady et al., 2018)

\begin{tabular}{|c|c|}
\hline Properties & Natural Soil \\
\hline Texture & Clay \\
\hline Electrical Conductivity $(1: 1)\left(\mathrm{dS} \mathrm{m}^{-1}\right)$ & 9.18 \\
\hline $\mathrm{pH}$ & 7.56 \\
\hline $\mathrm{Ca}^{2+}(\mathrm{ppm})$ & 780 \\
\hline $\mathrm{K}^{+}(\mathrm{ppm})$ & 109.5 \\
\hline $\mathrm{Na}^{+}(\mathrm{ppm})$ & 2240 \\
\hline $\mathrm{Mg}^{2+}(\mathrm{ppm})$ & 585 \\
\hline $\mathrm{Cl}^{-}(\mathrm{ppm})$ & 2441.5 \\
\hline $\mathrm{SO}_{4}{ }^{2-}(\mathrm{ppm})$ & 1031.3 \\
\hline Hydraulic Conductivity $\left(\mathrm{cm} \mathrm{s}^{-1}\right)$ & $1.83 \times 10^{-4}$ \\
\hline
\end{tabular}

Perforated cathode pipe SEKR system (PCPSS)
Recently, we have invented a new variation of soil electrokinetic remediation known as perforated cathode pipe SEKR system (PCPSS) as shown in Figs 1a and $1 b$. The main purpose of the PCPSS was to enhance the vertical electro-migration of heavy metals and soil elements. As it depicted in Figs 1a and 1b, the PCPSS approach will force electro-migration and electroosmosis in one-way flow towards the perforated cathode pipes. This allows to collect heavy metals containing wastewater in an underground drainage system that is already exist in Egyptian clay soil. The details information about the PCPSS may be found in our previous studies (Abou-Shady, 2012; Abou-Shady and Peng, 2012; Abou-Shady, 2016b).

As a new generation of SEKR there were several technical problems appeared with the primary investigation of the PCPSS. This motivated us to improve the original design of the PCPSS with a five new designs. The vertical anode/ perforated cathode pipe SEKR system (VA/PCPSS) was recommended as the most alternative design to overcome drawbacks raised during the operation of the PCPSS as shown in Fig. 1 c (Abou-shady et al., 2018).
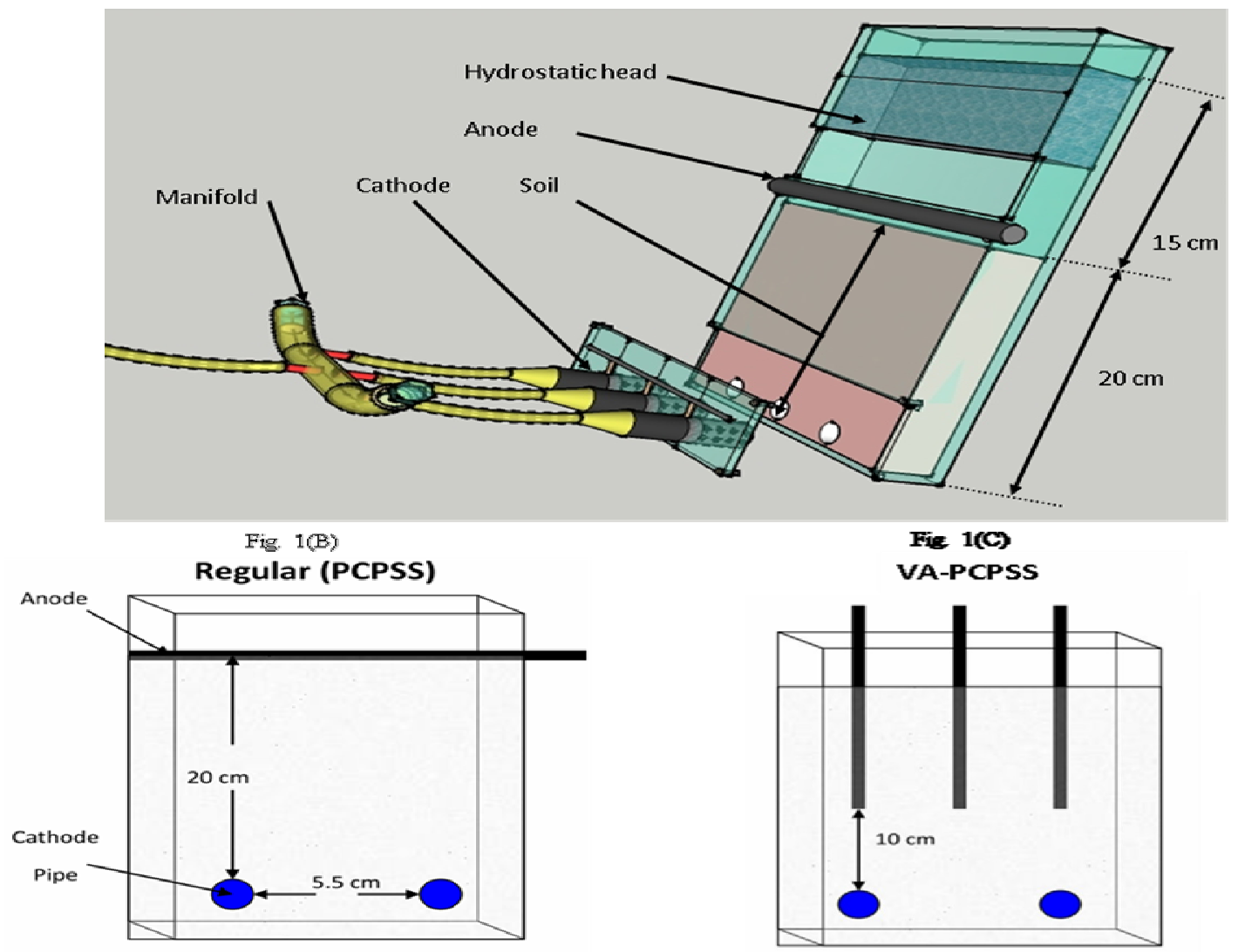

Fig. 1. A) Schematic sketch of perforated cathode pipe SEKR system (PCPSS), b) Schematic diagram of the PCPSS and C) Schematic diagram of the vertical anode/perforated cathode pipe SEKR system (VA/PCPSS) (Abou-shady et al., 2018) 


\section{Methodology}

Soil cations and anions were determined in soil solution 1:1 using ion chromatography (Dionex ICS1100). After terminating the treatment period (23 day), $\mathrm{Ca}^{+}, \mathrm{Mg}^{2+}, \mathrm{B}$, and $\mathrm{Mo}$ were detected in soil digest solution simultaneous with heavy metals detection using Inductivity Coupled Argon Plasma (ICAP 6500 Duo, Thermo Scientific England). In the same digest solution, the concentrations of $\mathrm{Na}^{+}$and $\mathrm{K}^{+}$were measured using Flamephotometer (CL378, India). Fixed applied potential $40 \mathrm{~V}(20 \mathrm{~V} \mathrm{~cm} \mathrm{1)}$ was set for ether the PCPSS or the VA/PCPSS. Fifty samples were taken to represent the whole specimen. The contour maps were drawn using (Surfer 10).

\section{RESULTS AND DISCUSSION}

$\mathrm{Ca}^{2+}$ behavior during the remediation of heavy metals containing soil using the PCPSS and the VA/PCPSS

Calcium ion is a vital element for plant growth and also important for soil structure, it plays an important role for creating soil aggregates that eventually improves soil physical and chemical properties (Dontsova and Norton, 1999; White and Broadley, 2003; Warton and Matthiessen, 2005; Wuddivira and Camps-Roach, 2007). The studied soil contained $\mathrm{Ca}^{2+}$ at concentration of $780 \mathrm{mg} \mathrm{kg}^{-1}$. During electrokinetic pollutant removal of heavy metals, $\mathrm{Ca}^{2+}$ containing saline soils will migrate towards cathode pipe via electro-migration, electro-osmosis, and diffusion using either the PCPSS or the VA/PCPSS. The continuously depletion of $\mathrm{Ca}^{2+}$ from saline soil may reflect a negative impact on soil aggregate that eventually decreases soil hydraulic conductivity and electro-osmosis during the operation of soil electrokinetic remediation (AbouShady, 2016b). Previous investigations indicated that the VA/PCPSS overcome the formation of $\mathrm{pH}$ jumping and unsaturated zone as it presented in Figs. $2 \mathrm{a}$ and $2 \mathrm{~b}$ (Abou-shady et al., 2018). Data presented in Fig. 3a shows that $\mathrm{Ca}^{2+}$ completely removed from the upper surface of soil specimen when the PCPSS was installed. In the $\mathrm{pH}$ jumping zone, the removed $\mathrm{Ca}^{2+}$ was achieved approximately 50\%. When the PCPSS was used, $\mathrm{Ca}^{2+}$ concentrations around perforated cathode were almost constant and the lowest values were notified close to anode. Applying the VA/PCPSS did not markedly change $\mathrm{Ca}^{2+}$ concentrations in the top surface of soil specimen, However, $\mathrm{Ca}^{2+}$ was depleted from the middle of specimen when the VA/PCPSS was used. It was clear that, $\mathrm{Ca}^{2+}$ accumulated adjacent to cathode pipes. We suggest that, to ensure high performance during the reclamation of saline clay soil the PCPSS should be used firstly as a primary treatment that may be followed by the VA/PCPSS.
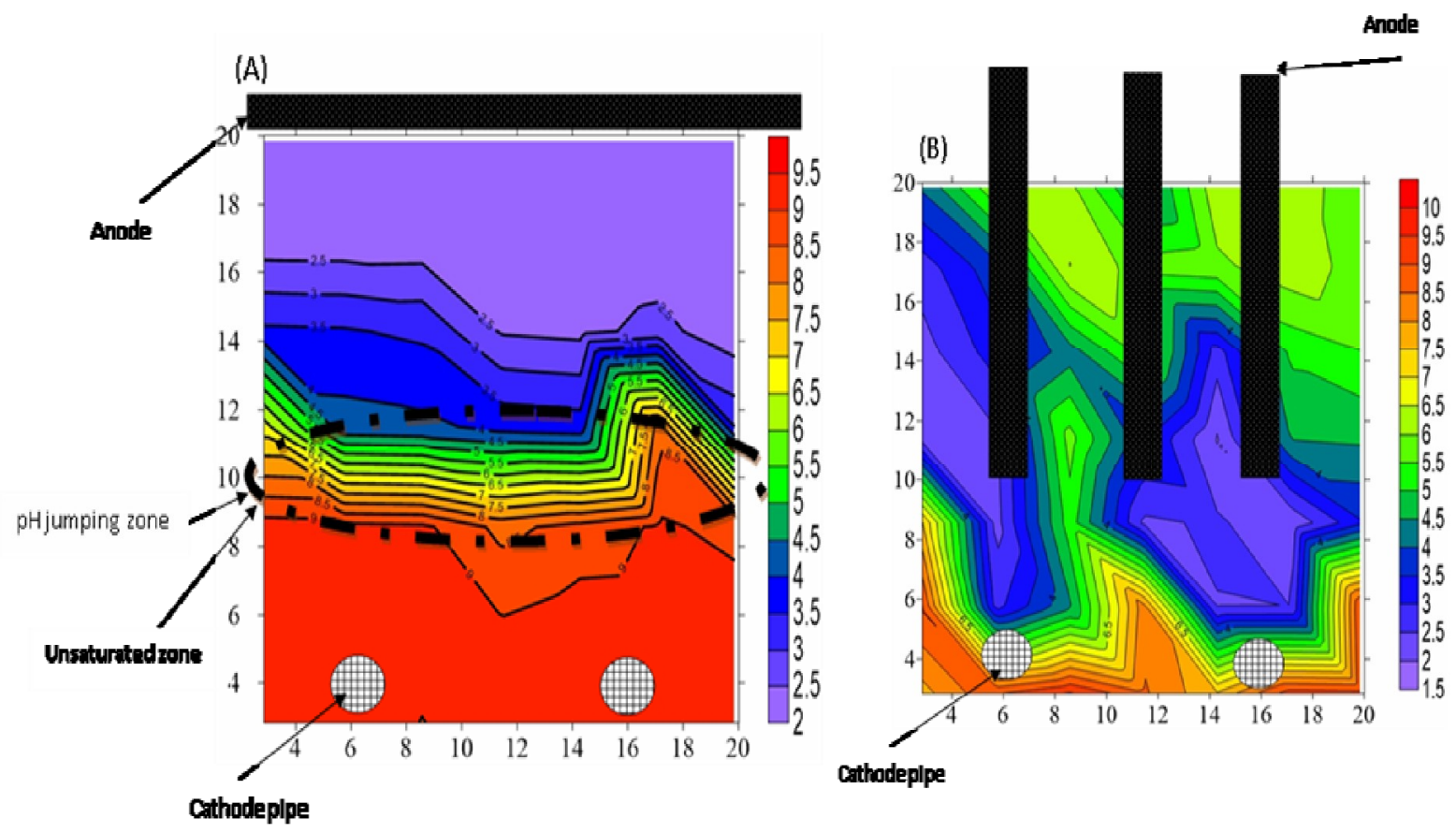

Fig. 2. pH distribution in the soil electrokinetic specimen A) the PCPSS and B) the VA/PCPSS (Abou-shady et al., 2018) 


\section{(A)}

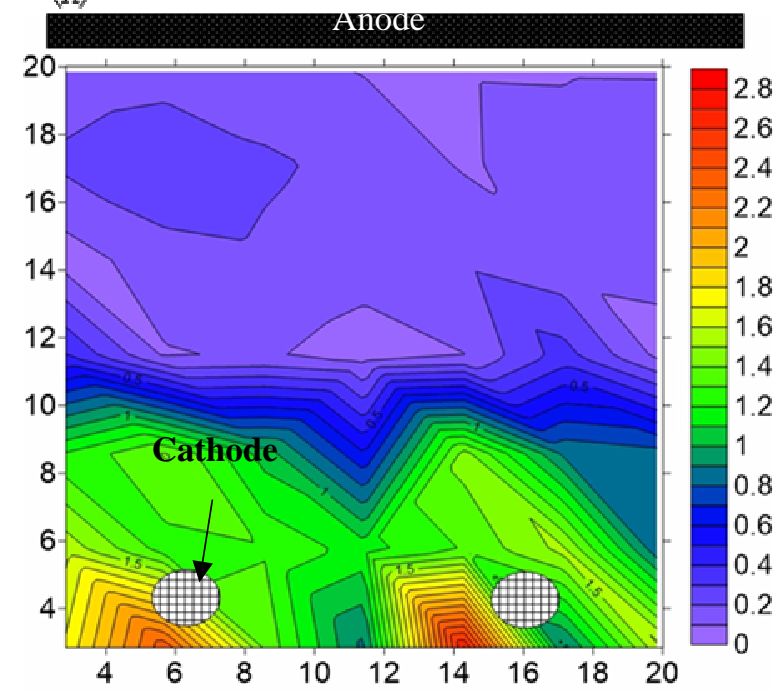

Anode

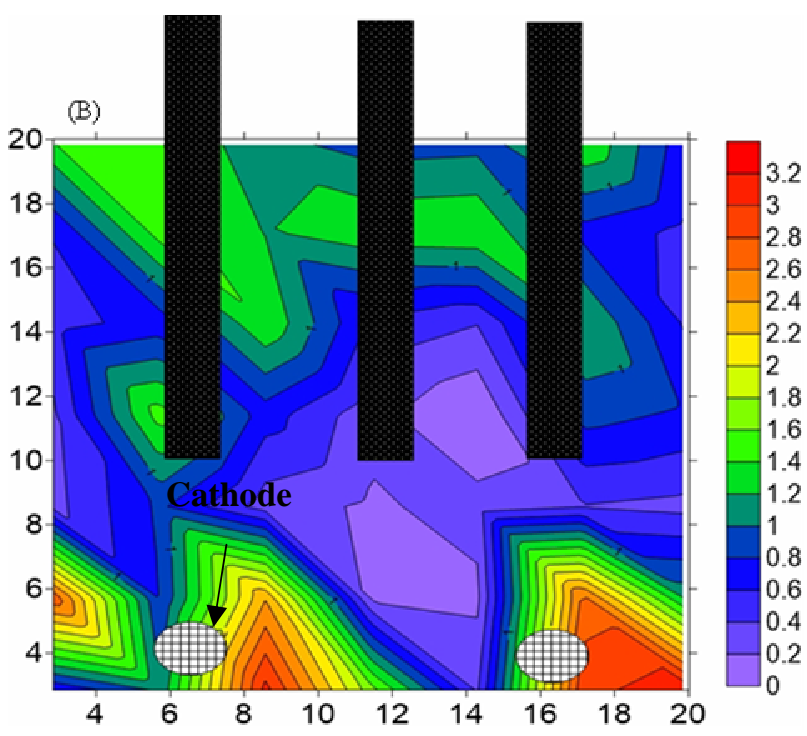

Fig. 3. Distribution of $\mathrm{Ca}^{2+}$ in the treated soil using $\mathrm{A}$ ) the PCPSS and $\mathrm{B}$ ) the VA/PCPSS

$\mathrm{Mg}^{2+}$ behavior during the remediation of the PCPSS and the VA/PCPSS

$\mathrm{Mg}^{2+}$ existed is saline soil with relatively low concentrations (585 mg kg${ }^{-1}$ ) compared with $\mathrm{Ca}^{2+}$ and $\mathrm{Na}^{+}$(Table 1). In general, the effect of $\mathrm{Mg}^{2+}$ concentrations on the formation of soil aggregates was lower than $\mathrm{Ca}^{2+}$ (Dontsova and Norton, 1999). $\mathrm{Mg}^{2+}$ containing soil should be adequate for pant requirements otherwise several physiologic functions will be appeared owing to the interrelated processes (Kirkby and Mengel, 1976). Fig. (4a) shows that $\mathrm{Mg}^{2+}$ depleted from the area close to the horizontal anode in the PCPSS regular design and re-adsorbed in subsequent layer (upper half of the PCPSS specimen). The same tendency was observed in the lower half of the PCPSS specimen. The removed $\mathrm{Mg}^{2+}$ was comparatively lower than $\mathrm{Ca}^{2+}$. In the depletion zone, the removed $\mathrm{Mg}^{2+}$ was close to $50 \%$. The accumulation of $\mathrm{Mg}^{2+}$ was observed in the gap between cathode pipes. Applying the VA/PCPSS enhanced the removed $\mathrm{Mg}^{2+}$ from the right part of top surface (around vertical cathode) and accumulated in the left part as shown in (Fig. 4b).
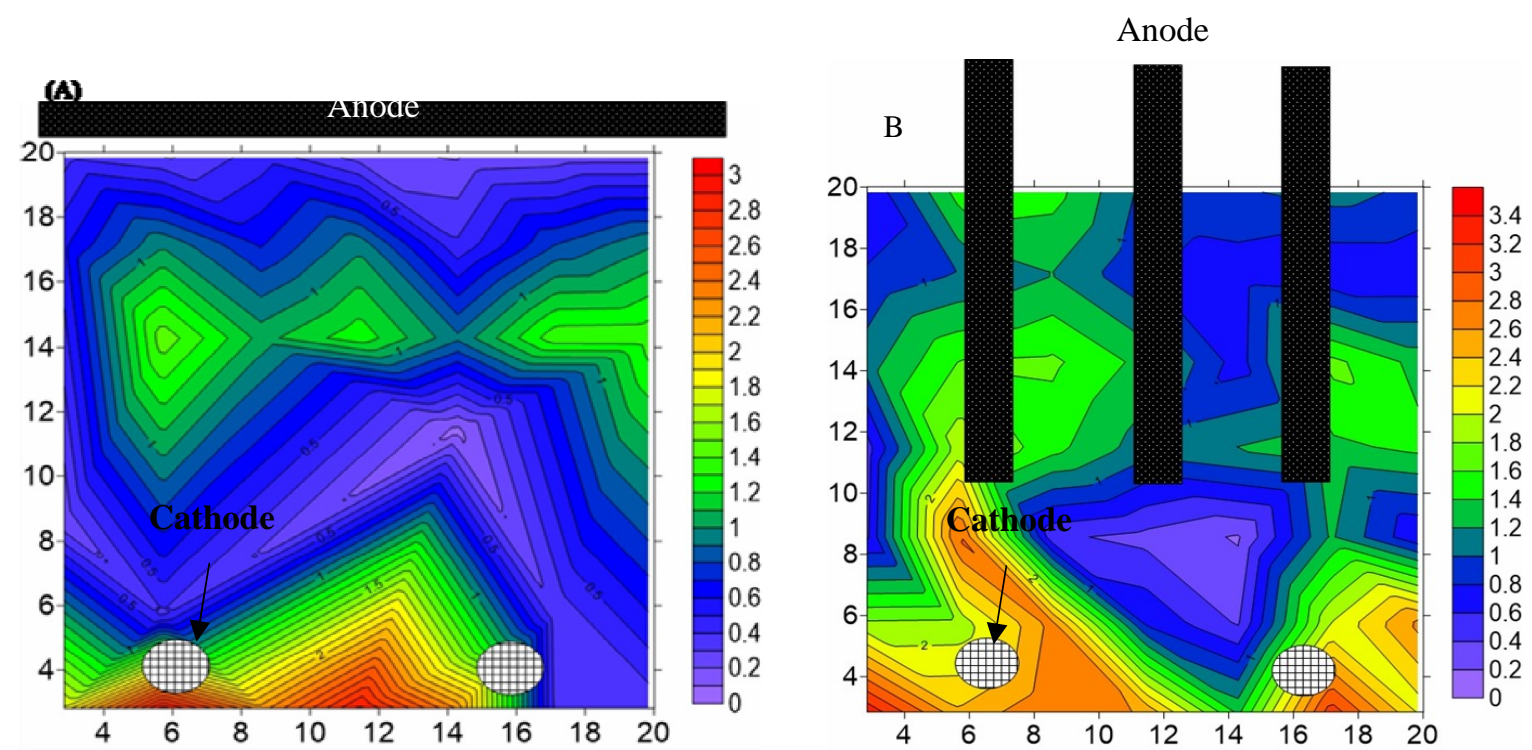

Fig. 4. Distribution of $\mathrm{Mg}^{2+}$ in the treated soil using A) the PCPSS and B) the VA/PCPSS 

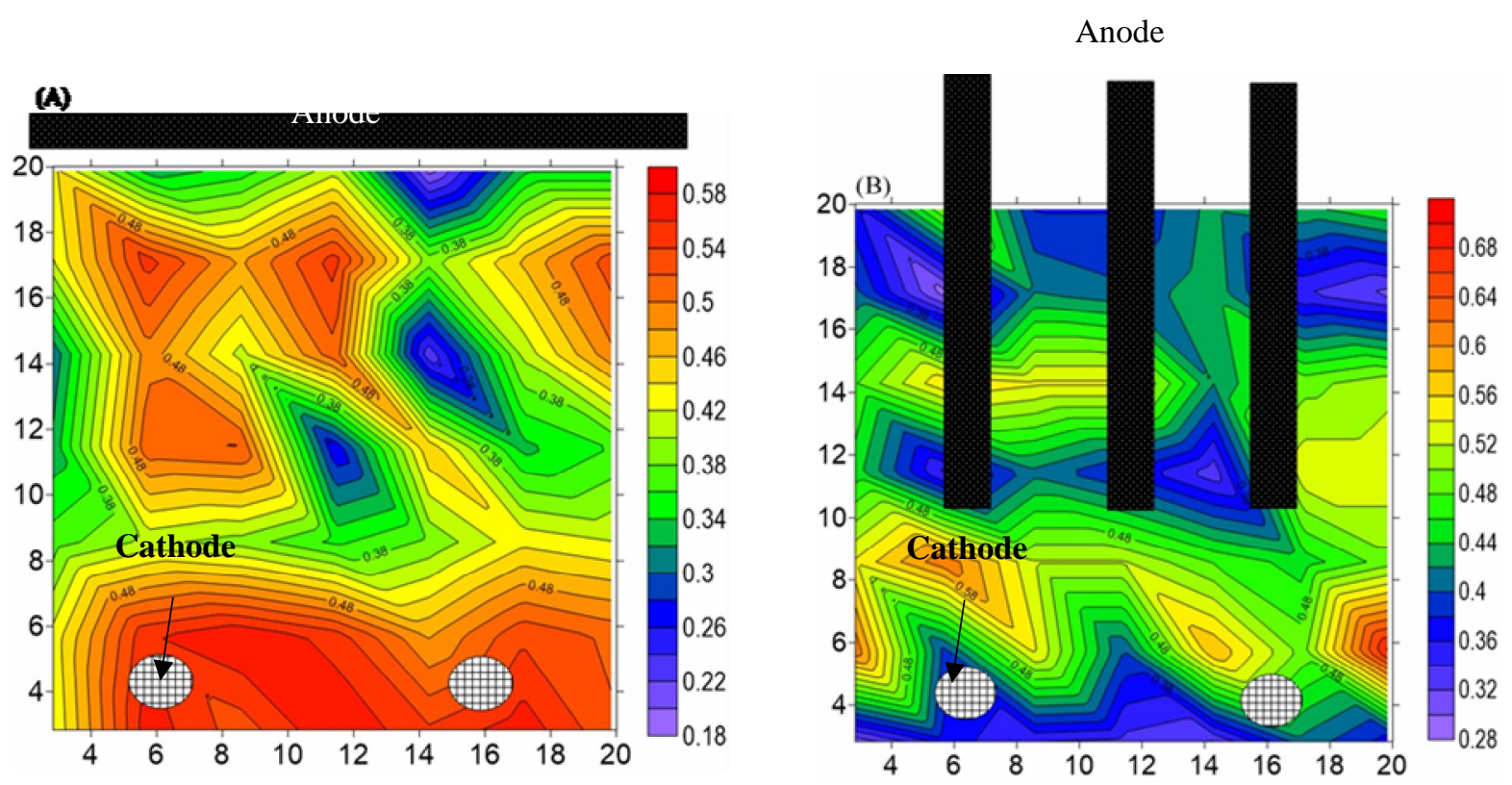

Fig. 5. Distribution of $\mathrm{Na}^{+}$in the treated soil using A) the PCPSS and $\mathrm{B}$ ) the VA/PCPSS

The VA/PCPSS succeeded in preventing the readsorption of $\mathrm{Mg}^{2+}$ in middle of specimen in the right part of specimen. Inserting vertical anode in the VA/PCPSS design induced the movement of $\mathrm{Mg}^{2+}$ from the gap between cathode pipes to outside. Accordingly, to ensure the best removal of $\mathrm{Mg}^{2+}$ during saline soil electro-reclamation the, installation of the PCPSS should be followed by the VA/PCPSS.

\section{$\mathrm{Na}^{+}$behavior during the remediation of the PCPSS and the VA/PCPSS}

Sodium ion in saline soils is considered the dilemma in arid and semi-arid countries owing to its negative impact on the formation of soil aggregates that eventually decreases hydraulic conductivity (AbouShady, 2016b). Relatively high concentrations of $\mathrm{Na}^{+}$ $\left(2240 \mathrm{mg} \mathrm{kg}^{-1}\right)$ was measured in soil solution compared with $\mathrm{Ca}^{2+}$ and $\mathrm{Mg}^{2+}$. Generally, the removed $\mathrm{Na}^{+}$was more than $50 \%$ in either the PCPSS or the VA/PCPSS, as it depicted in Fig. (5). The removed $\mathrm{Na}^{+}$was much better in the VA/PCPSS than the PCPSS particularly close to perforated cathode pipe. $\mathrm{Na}^{+}$accumulated close to cathode pipe in the PCPSS regular design. The accumulation of $\mathrm{Na}^{+}$in the VA/PCPSS was much lower than the PCPSS and depleted from the horizontal zone above cathode pipe. The removed $\mathrm{Na}^{+}$was much better with the VA/PCPSS technique than the PCPSS. Ongoing investigation focusing on improving the removal rate of $\mathrm{Na}^{+}$over $\mathrm{Ca}^{2+}$ and $\mathrm{Mg}^{2+}$ from saline soils via improving the VA/PCPSS technique.

\section{$\mathrm{K}^{+}$behavior during the remediation of the PCPSS} and the VA/PCPSS

From agricultural point of view, $\mathrm{K}^{+}$is considered as one of the three major nutrients (NPK) essential elements for plant growth (Wang et al., 2013). $\mathrm{K}^{+}$showed comparatively low concentrations levels in saline clay soil $190.5 \mathrm{mg} \mathrm{kg}^{-1}$ compared with $\mathrm{Ca}^{2+}, \mathrm{Mg}^{2+}$, and $\mathrm{Na}^{2+}$. The removal of $\mathrm{K}^{+}$was high when the PCPSS was installed compared with the VA/PCPSS in the upper half of electrokinetic specimen as presented in Figs. (6 a and b). Accordingly, the VA/PCPSS is highly recommended to avoid the depletion of $\mathrm{K}^{+}$and to ensure soil sustainability for agricultural purpose. The lower removal rate of $\mathrm{K}^{+}$may be owing to the capture of $\mathrm{K}^{+}$inside clay layers. On the other hand, the depletion of $\mathrm{K}^{+}$in the lower half of soil specimen was comparatively high when the VA/PCPSS was installed. This is may be due to the relatively high pulling force close to the cathode pipes (Abou-Shady and Peng, 2012).

\section{Boron behavior during the remediation of the PCPSS and the VA/PCPSS}

If born exist in traces amounts, it may vital for plant maturity, flower set, and water balance (Whittington, 1957; Bhat, 2013; Ganie et al., 2013; Ag-Info Centre). Boron existed in saline clay soil with total amount of $48.7 \mathrm{mg} \mathrm{kg}^{-1}$. Boron depleted from the middle of the PCPSS specimen and accumulated around anode electrode because of the negatively charged atom surface, as shown in Fig. (7a). Accordingly, plants grown in polluted soil treated with the PCPSS will 
suffer from boron toxicity. The VA/PCPSS overcame boron depletion from the middle of soil specimen as it shown in Fig. 7b. Applying the VA/PCPSS did not affect negatively on the distribution of boron throughout soils. Accordingly, the VA/PCPSS will be more appropriated with boron heavy metals containing polluted soil with heavy metals.

Mo behavior during the remediation of the PCPSS and the VA/PCPSS

Molybdenum may be a vital element for plant growth at low concentrations (Zimmer and Mendel, 1999; Kaiser et al., 2005). The total concentration of

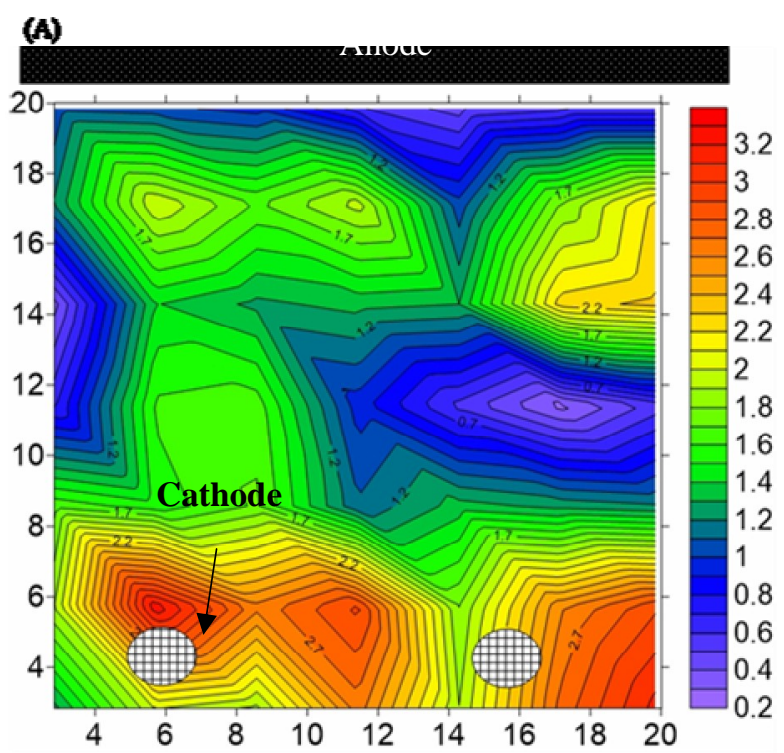

Fig. 6. Distribution of $\mathrm{K}^{+}$in the treated soil using A) the PCPSS and B) the VA/PCPSS
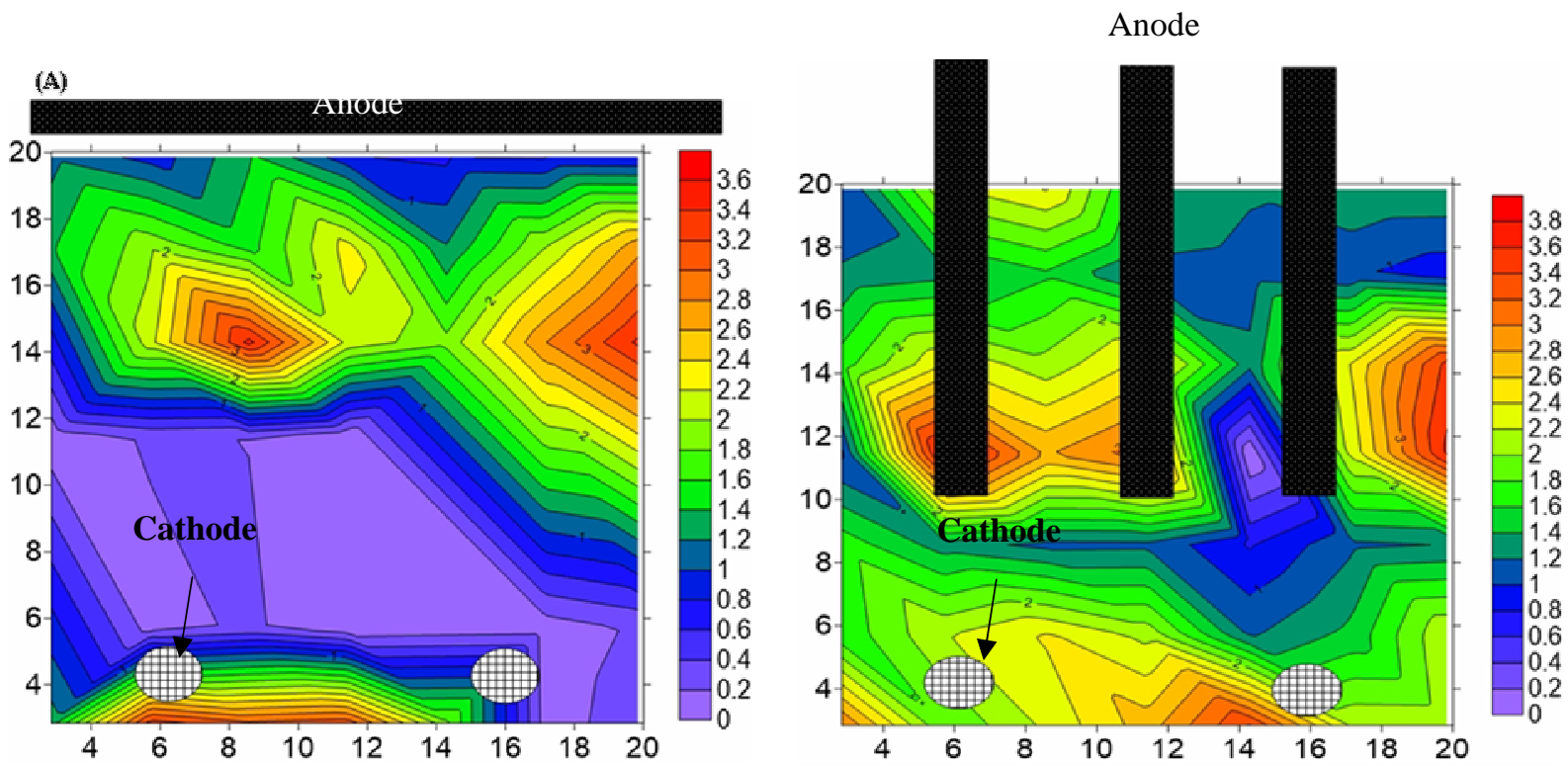

Fig. 7. Distribution of $B$ in the treated soil using $A$ ) the PCPSS and B) the VA/PCPSS
Mo in saline clay soil was as low as $0.88 \mathrm{mg} \mathrm{kg}^{-1}$. Mo distribution inside the PCPSS system is shown in Fig. 8a. It is clear that, Mo removal tended to osculate throughout soil specimen, this may be because of its comparatively low concentrations in the treated soil. The application of the VA/PCPSS resulted in the depletion of Mo from the area adjacent to anodes end and cathode pipes as presented in Fig. (8b). Accordingly, Mo re-distribution after electrokinetic remediation did not negatively affect by neither the PCPSS nor the VA/PCPSS

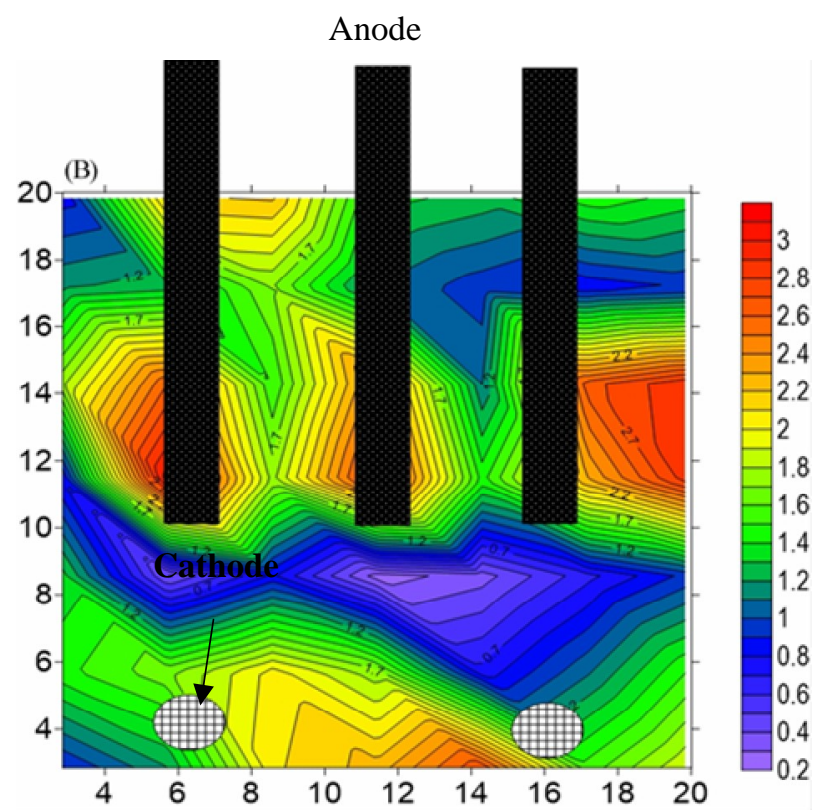




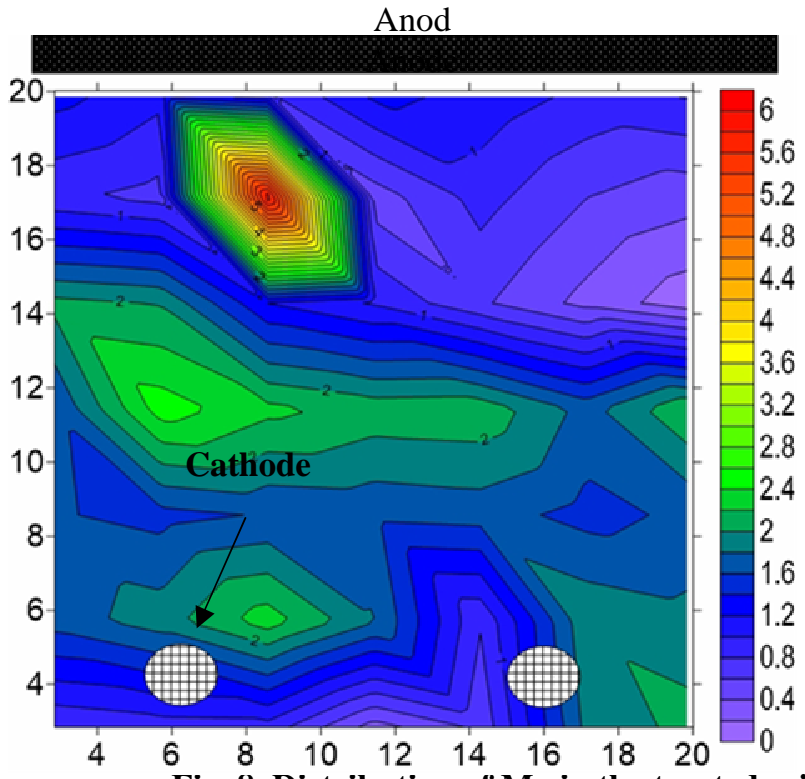

Fig. 8 . Distribution of Mo in the treated so

Ongoing researches will be focused on improving the performance of the VA/PCPSS to treat heavy metals containing sewage sludge in which pilot scale experiments will be established using continuouslyreoriented electric field (Almeria et al., 2012; Peng et $a l ., 2013)$. The heavy metals containing outlet discharge will be treated simultaneously using integrated electrodialysis, electrolysis, and adsorption (AbouShady et al., 2011; Bi et al, 2011; Peng et al., 2011; Abou-Shady et al., 2012a; Abou-Shady et al., 2012b; Jin et al., 2102) Also, the redistribution of humic substances during soil electrokinetic remediation will be taken into consideration (Aboushady, 2008; Khalil et al, 2009).

\section{Conclusions}

Two different techniques were developed to remediate heavy metal containing polluted soil. The first technique was perforated cathode pipe SEKR system (PCPSS), and the second technique was the vertical anodes/perforated cathode pipe SEKR system (VA/PCPSS). In the present work, the behavior of some macro and micro element was investigated during the remediation of heavy metals containing polluted soil. The obtained resulted are summarized as follows:

1) High removal of $\mathrm{Ca}^{2+}$ was observed in the top layer close to anode when the PCPSS was applied and tended to accumulate close to cathode pipes. On the other hand, in the VA/PCPSS $\mathrm{Ca}^{2+}$ was depleted from the middle of soil specimen.

2) The removal percentage of $\mathrm{Mg}^{2+}$ was lower than $\mathrm{Ca}^{2+}$. The $\mathrm{Mg}^{2+}$ desorbed from the layer close to

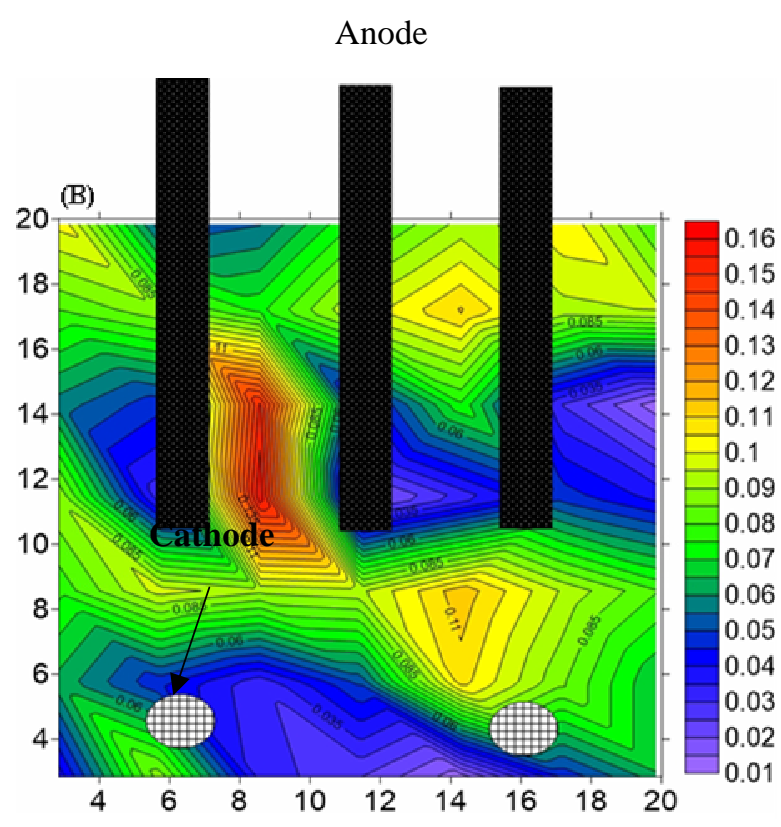

sing A) the PCPSS and B) the VA/PCPSS

anode and re-adsorbed in the subsequent layer in the PCPSS technique. On the other hand, the application of the VA/PCPSS shunned this accumulation.

3) The removed $\mathrm{Na}^{+}$was more than $50 \%$ in either the PCPSS or the VA/PCPSS. In general, the removal rate using the VA/PCPSS was higher than the PCPSS.

4) The removal rate of $\mathrm{K}^{+}$was high during the PCPSS compared with the VA/PCPSS.

5) Boron depleted from the middle of the PCPSS and migrated toward the anode. The VA/PCPSS avoided this accumulation that may be considered as an agricultural value.

6) Molybdenum removal tended to osculate throughout soil specimen, this may be because of its comparatively low concentration in the treated soil.

\section{Acknowledgments}

This work was funded by the Desert Research Center (DRC), Egypt. Research No. 1546.

\section{REFERENCES}

Aboushady, A. 2008. Effect of humic substance on the behaviors of heavy metals in alluvial and calcareous soils. M.Sc. Dissertation, Minufiya University, Egypt.

Abou-Shady, A. 2012. Removal of Pb (II) from wastewater and polluted soil by electrical technologies. $\mathrm{PhD}$ Dissertation, Ocean University of China, China.

Abou-Shady, A. 2016a. Effect of separated cathode on the removal of dissolved organic carbon using anode oxidation, Fenton oxidation, and coagulation. J. Environ. Chem. Eng. 4 (1): 704-710. 
Abou-Shady, A. 2016b. Reclaiming salt-affected soils using electro-remediation technology: PCPSS evaluation. Electrochimica Acta. 190: 511-520.

Abou-Shady, A. 2017. Recycling of polluted wastewater for agriculture purpose using electrodialysis: Perspective for large scale application, Chem. Eng. Journal .323: 1-18.

Abou-Shady, A. and C. Peng. 2012. New process for ex-situ electrokinetic pollutant removal I: process evaluation. J. Ind. Eng. Chem. 18: 2162-2176.

Abou-Shady, A., Eissa, D., Abdelmottaleb, O. and H. Rehab. 2018. New approaches to remediate heavy metals containing polluted soil via improved PCPSS. J. Environ. Chem. Eng. 6: 1322-1332.

Abou-Shady, A., Peng, C., Almeria, J.O. and H. Xu. 2012b. Effect of $\mathrm{pH}$ on separation of $\mathrm{Pb}$ (II) and $\mathrm{NO} 3$ from aqueous solutions using electrodialysis. Desalination. 285: $46-53$.

Abou-Shady, A., Peng, C., Bi, J., Xu, H. and J.O. Almeria. 2012. Recovery of $\mathrm{Pb}$ (II) and removal of NO3 from aqueous solutions using integrated electrodialysis, electrolysis, and adsorption process. Desalination. 286 304-315.

Abou-Shady, A., Xu, H., and C. Peng. 2011. Production of pure water suitable for laboratory experiments by electrodialysis technology, 5th International Conference on Bioinformatics and Biomedical Engineering, Wuhan, China, IEEE, doi:10.1109/icbbe.2011.5780963.

Ag-Info Centre. Data was obtained from the following website:

(http://www1.agric.gov.ab.ca/\$department/deptdocs.nsf/al 1/agdex789).

Almeria, J.O., Peng, C., and A. Abou-Shady. 2012. Enhancement of ion transport in porous media by the use of a continuously-reoriented electric field, J Zhejiang Univ-Sci A (Appl Phys \& Eng). 13 (7): 546-558.

Bi, J., Peng, C., Xu, H. and A. Ahmed. 2011. Removal of nitrate from groundwater using the technology of electrodialysis and electrodeionization. Desalin. Water Treat. 34: 394-401.

Dontsova, K., and L. Norton. 1999. Effect of exchangeable $\mathrm{Ca}: \mathrm{Mg}$ ratio on soil clay flocculation, infiltration and erosion. Selected papers from the $10^{\text {th }}$ international soil conservation organization meeting held May.24-29.
Ganie, M.A., Akhter, F., Bhat, M. A., Malik, A. R., Junaid, J.M., Shah, M.A., Bhat A. H. and T.A. Bhat. 2013. Boron - a critical nutrient element for plant growth and productivity with reference to temperate fruits. Current Sci. 104: 76-85.

Jin, R., Peng, C., Abou-Shady, A., and K. Zhang. 2012. Recovery of precious metal material $\mathrm{Ni}$ from nickel containing wastewater using electrolysis. Applied Mechanics and Materials. 164: 263-267.

Kaiser, B.N., Gridley, K., Brady, J.N., Phillips, T., and S.D. Tyerman. 2005. The Role of Molybdenum in Agricultural Plant Production. Ann Bot. 96 (5): 745-754.

Khalil, R., Abou-Hussien, E. Radwan, S., and A. Aboushady. 2009. Distribution of humic and fulvic acids in alluvial and calcareous soils. Minufiya J. Agric. Res. 1 (34): 311324.

Kirkby, E. A. and K. Mengel. 1976. The role of magnesium in plant nutrition. J. Plant Nutr. Soil Sci. 139 (2):209-222.

Peng, C., Almeria, J.O., and A. Abou-Shady. 2013. Enhancement of ion migration in porous media by the use of varying electric fields, Sep. Purif. Technol. 118C: 591597.

Peng, C., Liu, Y., Bi, J., Xu, H., and A. Ahmed. 2011. Recovery of copper and water from copper-electroplating wastewater by the combination process of electrolysis and electrodialysis. J. Hazard Mater. 189: 814-820.

Wang, M., Zheng, Q., Shen, Q. and S. Guo. 2013. The Critical Role of Potassium in Plant Stress Response. Int J Mol Sci. 14(4): 7370-7390.

Warton, B. and J.N. Matthiessen. 2005. The crucial role of calcium interacting with soil $\mathrm{pH}$ in enhanced biodegradation of metam-sodium. Pest Manag Sci. 61(9): 856-62.

White, P.J. and M. Broadley. 2003. Calcium in plants. Ann Bot 92: 487-511.

Whittington, W. J. 1957. The role of boron in plant growth: The effect on general growth, seed production and cytological behavior. J Exp Bot. 8 (3): 353-367.

Wuddivira, M. N. and G. Camps-Roach. 2007. Effects of organic matter and calcium on soil structural stability. Europ. J. Soil Sci. 58 (3): 722-727.

Zimmer, W. and R. Mendel, 1999. Molybdenum Metabolism in Plants. Plant Biol. 1: 160-168. 


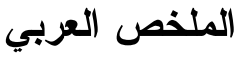

\section{تاثير المعالجة الكهربية للملوثات على حالة بعض العناصر الكبرى والصغرى فى الارض الملحية}

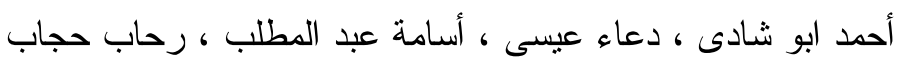

المغنسيوم المزال قد تم از التة من طبقة و تر اكمة فى الطبقة

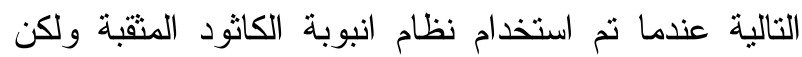
هذة الملاحظة لم تظهر عندما قمنا باستخدام نظام اقطاب الانود العمودى المصاحب للانبوبة الكانود المثقبة. بالنسبة للبوتاسيوم المزال من الطبقة السطحية فانة كان بكمية اقل من باقى الاماكن الموجودة فى عمود التربة فى حالة استخدام نظام اقطاب الانود العمودى المصاحب لانبوبة الكاثود المثقبة مما يشجع استخدام هذا النظام فى الار اضى الإدى المقترح زراعتها مرة اخرى بعد المعالجة الكهربية لها.

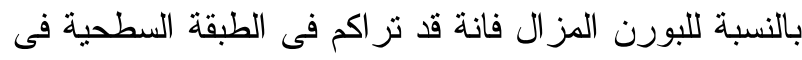
نظام انبوبة الكاثود المثقبة، هذة الملاحظة قد تم تفاديها باستخدام نظام اقطاب الانود العمودى المصاحب لانبوبة الكاثود المثقبة. واوضحت النتائج المتحصل عليها و الخاصة بالمولبيدنيوم باعادة نوزيعة فى عمود التربة نتيجة لاستخدام

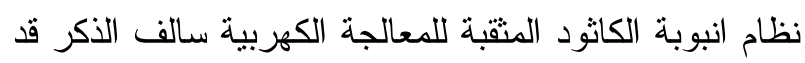
تذبذبت من مكان الى اخر. ولكن باستخدام نظام اقطاب

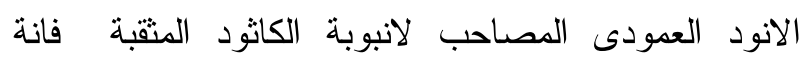
لوحظ زيادة الكمية المز الة من المولبيدنيوم بالقرب من نهاية اقطاب الانود العمودية وحول انبوبة الكاثود المثقبة.
تعتبر المعالجة الكهربية من التقنيات الملائمة لازلة

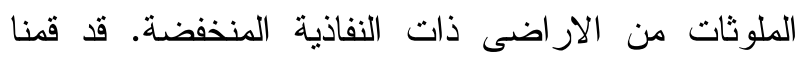
حديثا بتطوير جيل جديد من المعالجة الكهربية معرف حاليا

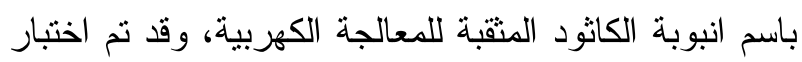
هذة الطريقة لإزلة الفلزات الثقلية وكذلك استصلاح الار اضى الملحية. تم تحديث نظام انبوبة الكاثود المثقبة للمعالجة الكهربية لإزالة الفلز ات الثقيلة وذلك بتقديم نظام جديد يعرف بنظام اقطاب الانود العمودى المشارك لانبوبة

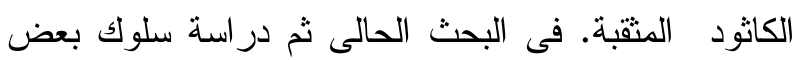

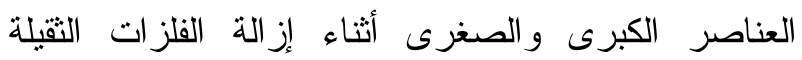
الموجودة فى الارض باستخدام نظامى انبوبة الكاثود المثقبة

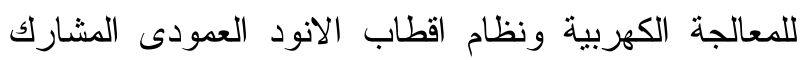

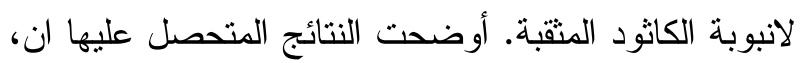

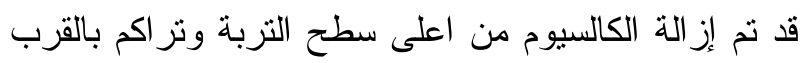

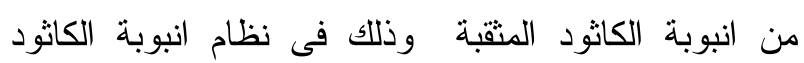

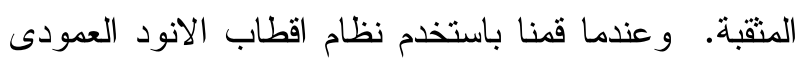

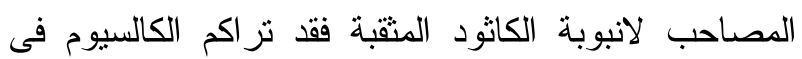
منتصف عمود التربة. وبصفة عامة وجد ان كمية الماغنسيوم المزال بهاتين الطريقين كان اقل بكثير بالمقارنة

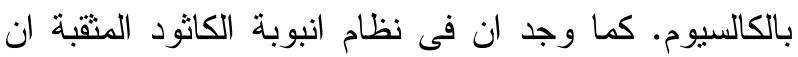

